IZA DP No. 5281

Norms, Culture and Local Infrastructure:

Evidence from a Decentralised Economy

Sarmistha Pal

October 2010 


\title{
Norms, Culture and Local Infrastructure: Evidence from a Decentralised Economy
}

\author{
Sarmistha Pal \\ Brunel University \\ and IZA
}

\section{Discussion Paper No. 5281 \\ October 2010}

\author{
IZA \\ P.O. Box 7240 \\ 53072 Bonn \\ Germany
}

Phone: +49-228-3894-0

Fax: +49-228-3894-180

E-mail: iza@iza.org

\begin{abstract}
Any opinions expressed here are those of the author(s) and not those of IZA. Research published in this series may include views on policy, but the institute itself takes no institutional policy positions.

The Institute for the Study of Labor (IZA) in Bonn is a local and virtual international research center and a place of communication between science, politics and business. IZA is an independent nonprofit organization supported by Deutsche Post Foundation. The center is associated with the University of Bonn and offers a stimulating research environment through its international network, workshops and conferences, data service, project support, research visits and doctoral program. IZA engages in (i) original and internationally competitive research in all fields of labor economics, (ii) development of policy concepts, and (iii) dissemination of research results and concepts to the interested public.
\end{abstract}

IZA Discussion Papers often represent preliminary work and are circulated to encourage discussion. Citation of such a paper should account for its provisional character. A revised version may be available directly from the author. 


\section{ABSTRACT}

\section{Norms, Culture and Local Infrastructure: Evidence from a Decentralised Economy ${ }^{*}$}

Culture as reflected in social and religious norms may be pivotal to social organization in a decentralised economy where local authorities are responsible for the provision of local public goods. We distinguish between individualist and collectivist cultures to argue that collectivist culture may promote rules to indulge in family, social and religious values at the cost of individual values promoting material objects and may thus result in inefficient choice of pubic goods. We use Indonesia as a case in point to classify communities strictly adhering to traditional adat laws and Islamic religion as promoting collectivist culture. Results using 1997 and 2007 Indonesian Family Life Survey community-level panel data highlight that, even after controlling for other variables, traditional collectivist communities strongly adhering to adat and Islam tend to have significantly greater access to social (rather than physical) infrastructural goods; similar pattern is reflected in the allocation of community spending to these goods.

JEL Classification: D02, H41, O43, P51

Keywords: decentralization, collectivist culture, adat law, Islam, social and physical infrastructure, allocation of spending, community development, Indonesia

Corresponding author:

Sarmistha Pal

Department of Economics and Finance

Brunel University

Kingston Lane

Uxbridge UB8 3PH, Middlesex

United Kingdom

E-mail: sarmistha.pal@brunel.ac.uk

\footnotetext{
* Financial support from Brunel University Research Leave Award and physical support from CSAE, Oxford who hosted me during this period are gratefully acknowledged. I am much grateful to Zaki Wahhaj for many discussions and comments; I would also like to thank Marcel Fafchamps, Sugata Ghosh, Rozanna Himaz, James Maws, Jean-Philippe Platteau, Matthew Rablen, Joydeep Roy as well as seminar participants at Brunel, CSAE and Minnesota for their comments and suggestions. Any errors are mine.
} 


\section{Norms, Culture and Local Infrastructure: Evidence from A Decentralised Economy}

\section{INTRODUCTION}

In recent years there has been a renewed interest to analyse whether the varied economic paths of different societies over time can be traced to differences in culture, customs, social norms and religion (e.g., see Guiso, Sapienza and Zingales, 2006). The present paper builds on this literature to assess the role of culture, as reflected in religious and social norms, on the provision of local public infrastructure in a decentralised economy, which remains little understood.

In an attempt to explain the apparent puzzle as to why do societies fail to adopt the institutional structure of more economically successful countries, Grief (1994), Platteau (2000), among others, have highlighted the role of culture, diverse social customs/beliefs/norms on economic development. Some social norms can provide an effective solution to the problem of social organisation while others can be harmful. For example, Grief (1994) highlights the merits of individualist (as opposed to collectivist) cultural beliefs for the formation of efficient agency relations in the context of medieval merchants. Putnam (1993) attributes the greater success of modern political institutions in northern Italy to the pre-existence of a strong civic culture. Bowles and Gintis (2004) argue how the ethnically linked parochial groups could achieve high levels of cooperation (i.e., inducing a collectivist culture) in informal contracts while engaging in exclusionary practices. Despite its importance, implications of culture- individualist or collectivist- for the provision of local public goods remain little understood. We argue that an understanding of culture is particularly relevant for the provision of local public goods and infrastructure especially in a decentralised economy where local governing bodies (rather than central government bureaucrats) have the authority to choose and provide these public goods.

Decentralization is by and large a political decision of national leadership that involves devolution of political or fiscal powers to local governing bodies responsible for the provision of local public goods and services. Thus decentralisation has important 
economic consequences for local community development. Standard models of collective action argue that the provision of public goods depends on group size and group effort subject to free-riding on others' efforts. Ethnic diversity may however impede collective action because of taste differences of different sections of the population (Alesina, Baqir and Easterly, 1999), unequal distribution of the benefits from public goods (Khwaja, 2008) and/or inability to impose social sanctions in ethnically diverse communities (e.g., Miguel and Gugerty, 2005). Others have highlighted the importance of various political economy considerations, e.g., elite capture (Bardhan and Mukherjee, 2000) or legislator identity (Chattopadhyay and Duflo, 2002; Pande 2003; Besley et al. 2005) on the provision of local public goods in decentralised economies.

We go beyond this literature to identify the possible role of culture on the choice of local public goods. In particular, following the influential work of cross-cultural psychologists (e.g., see Heine 2007), we distinguish between individualist and collectivist cultures. While individualist cultures emphasize rules promoting personal freedom and achievement at the expense of group goals, resulting in a strong sense of competition, collectivist cultures promote rules focusing on family and work group goals. Group, family or rights for the common good (rather than the rights of individuals) is seen as most important in collectivist cultures, where rules promote order and stability of the society. Accordingly, collectivist culture may help reconcile conflicting preferences for/against a particular public good, even if it is inefficient (see further discussion below). Persistence of irrational/inefficient community behaviour is also highlighted in some recent works within Economics. In particular, Kranton (1996) argues that personal connections within an ethnic group may promote informal reciprocal exchange (as opposed to monetary market exchange) even if it is inefficient, especially in smaller societies; reciprocity however disappears as market develops. Bowles and Gintis (2004) goes further to show how ethnically linked parochial groups could achieve high levels of cooperation while engaging in exclusionary practices. Behavioural economists tend to (e.g., Easterlin (1995)) tend to argue that raising income for all may not necessarily increase happiness for all. For one thing, individual orientation of material objects/values (which generates more income) conflicts with collective-oriented values, such as family 
values, social and religious values. This conflict may create psychological tension, thus lowering personal well-being (Borroughs and Reindfleish, 2002).

Indonesia is an important case in point which has a long tradition of political decentralisation although fiscal decentralisation (i.e., law 22/99) was introduced only in 2001. This justifies our interest in local communities as decision making units (see further discussion of local government in section 2). The Dutch colonial rule recognized village governments as lawful entities and encouraged self-rule according to Adat laws. There are also longstanding efforts to shape lives in an Islamic way. All these efforts are further complicated by the nation's attempt to impose modern state laws and decrees in the post-independent period with a view to remove local injustice and promote national integration. While adat laws were formally banned during Suharto’s regime, the formal ban did not result in the abandonment of these adat laws and the extensive decentralization process that followed the demise of Suharto in 1998 only reinstated them in 2001. Coexistence of Adat laws, Islamic Sharia laws and the positive laws of the modern state has thus defined Indonesia’s pluralistic identity.

Literally 'adat community' translates to 'autonomous' groups of indigenous people who are able to manage their lives without knowing western laws and established their own regulations and social control. Adat laws are a set of local and traditional norms concerning marriage/divorce, birth, living arrangements of the elderly, inheritance and dispute resolution systems, land rights, gender role and decision making in the household as well as in the community, which lays the foundation for a collectivist culture. Adat livelihoods are often linked to land, water and natural resources, thus giving rise to a culture that is primarily rural in nature and where the ethic of mutual co-operation has been of paramount importance. There are also penalties for breaking the traditional laws which may range from advisory talk to imposing fine/penalty, being isolated or even moved out of the community. ${ }^{1}$

Indonesia has also a long Islamic tradition, which has been marked by a historical division between 'traditional' and 'modern' Islamic values/practices. One can distinguish 'Muslim modernists', who seek to reform Indonesia, from the traditional ones. While the

\footnotetext{
${ }^{1}$ The likelihood of fine/penalty or even being isolated in case of breaking a traditional law is about $44 \%$ in strongly adat (which is about double than that in others) communities in our sample.
} 
traditional Islamic practices lean on Sharia laws and community integrity, Muslim modernists have close ties with the positive laws of the state, which is more individualistic in nature. Indonesians have also successfully harmonized the two legal traditions, namely adat and Islam. ${ }^{2}$

Set in this context, we assess the role of social and religious norms on choice/delivery of public infrastructural goods in a sample of 314 rural and urban communities in Indonesia. Our analysis is primarily based on Indonesian Family Life Survey (IFLS) community-level panel data-set for the period 1997-2007, which is an eventful time in the nation's history. ${ }^{3}$ This data allows us to classify communities into traditional and modern depending on their degree of adherence to adat laws and Islam. While communities strictly adhering to adat laws and Islamic religion are classified as traditional collectivist culture, others not doing so are labelled as individualist modern culture. Further support for this classification is obtained from the available information on the ethics of mutual co-operation in these communities (see discussion in section 2). This classification allows us to explore the role of culture, as reflected in social and religious norms, $\mathrm{n}$ differential choice of local infrastructure, if any.

In an attempt to assess the role of culture, as reflected in social and religious norms, on choice/delivery of local infrastructure, we distinguish between social (health and education) and physical (utility, transport, communications) public infrastructural goods. While investment in social infrastructural goods like health and education may directly contribute to skills and productivity of community people, thus facilitating production/exchange within the community, investment in physical infrastructure like transport and communications may facilitate individualism promoting market exchange, trade with outside communities and therefore material achievements as measured in terms

\footnotetext{
${ }^{2}$ It is envisaged that Adat and Islamic laws have existed side by side long before the intervention of the colonial powers in Indonesian legal affairs. The dialogue between the two sets of laws persists even in modern Indonesia which has been reflected in Indonesian laws on conditional repudiation, common property in marriage, obligatory bequest and also conflict resolution.

3 In an attempt to promote national integration, Suharto's New Order Period witnessed introduction of new policies and programmes including significant changes in property rights in land and other natural resources, which threatened the very basis of adat livelihoods. Onset of the economic crisis of the 1990s had cast a major blow to the infrastructural investment/ development in the country, which was followed by the overthrow of Suharto in 1998 and subsequently introduction of fiscal decentralisation in the new Millennium.
} 
of income and growth; the latter may however threaten the very basis of a traditional collectivist culture as laid in adat laws and Islamic religion promoting family, social and religious values. Thus in an attempt to preserve their traditional identity, traditional (i.e., Islamic adat) communities may rationally choose to invest more in social (rather than physical) infrastructural goods. Thus choice of social infrastructure within a collectivist culture may encourage conformity within society and discourages individuals from standing out. The latter can be particularly facilitated by the perception of a common external threat during Suharto's regime, giving rise to feelings of loyalty and norms of solidarity in an attempt to protect community identity/livelihood. In the absence of any prior evidence, we use the unique panel data at our access to test this central proposition.

It is an important exercise as access to public infrastructure is understood to be central to economic growth. Neglect in the provision of public capital and infrastructure can adversely affect the productivity of private capital (e.g., see Reinikka and Svensson, 2004). In contrast, good governments that invest in essential public goods and services realise high rates of return (e.g., see Easterly, 2001). Unlike most existing studies on Indonesia ${ }^{4}$, we use community-level panel data-set to examine the role of social and religious norms on the provision of physical and social infrastructural goods in the sample communities. Since culture is inherited at birth, we rule out bias arising from simultaneity between choice of infrastructure and adherence to a particular type of culture, thus focusing on a causal relationship between the two, if any. Use of panel data allows us to minimise any estimation bias arising from unobserved heterogeneity in the data.

Results highlight differential choice/delivery of infrastructural goods in traditional and modern communities. Ceteris paribus, there is evidence traditional communities strongly adhering to adat and Islam tend to have comparable/better access to social infrastructure (government schools and health facilities), but significantly lower access to some physical infrastructural goods like those linked to modern communications and

\footnotetext{
${ }^{4}$ For example, Beard (2007) examines the effects of various household characteristics on household contribution to community development, while Bandeira and Levy (2007) focus on the role of democratic decision making on the provision of a number of public goods in Indonesia. Both these studies however use single cross-section IFLS data-set: Beard (2007) used third round of IFLS data while Banderia and Levy's (2007) analysis is based on second round IFLS 1997. Olken (2007) in contrast use his own survey data to explore the political economy of public goods provision in Indonesia.
} 
transport. There is also confirmation that communities strictly adhering to adat and Islam tend to allocate significantly lower share of total development spending on local infrastructural goods. These results are robust to alternative specifications.

The analysis is developed as follows. Section 2 describes the data and research setting while section 3 analyses the results. The final section concludes.

\section{DATA DESCRIPTION}

The analysis has been based on the community-level data obtained from Indonesian Family Life Survey (IFLS) data. In addition to LSMS type household level data, IFLS provides very detailed information on communities. In particular, each round of IFLS contains information on 314 rural and urban communities drawn from 13 provinces including Jakarta, Bali, Java (central, east and south), Sumatra (north, west and south), Lampung, Wntenara and south Kalimantan (for further details on the data see Frankenberg and Thomas, 2000; Strauss et al. 2009). Although IFLS has been conducted in 1993, 1997, 2000, 2007, only IFLS rounds 1997 and 2007 contain information on community's adherence to adat laws and nature of governance; hence, our analysis makes use of 1997 and 2007 rounds of IFLS only.

Local government in Indonesia consists of a headman assisted by an appointed village assembly (LMD) throughout the country. Development projects and assistance were managed by community resilience boards (LKMD) who allocated development grants (mainly from the central government) across households and projects. Law 22/99, enacted by January 2001 gave villages more autonomy in raising local revenues replacing central grants, thus paving the way for fiscal decenralisation. Elections for both the headman and the council now take place every five years and the headman is directly accountable to the council. Use of 1997 and 2007 IFLS data thus allow us to consider the years before and after the introduction of fiscal decentralisation.

We focus on a number of basic infrastructural goods that could directly impact on sustainable livelihoods and provide opportunities for all, especially for the poor. First, the list of physical infrastructural goods includes community's access to cemented local roads PROAD (rather than national highways), motorized public transport PUBTRANS (public bus/boat), public telephone office PTO, post office PO. Since economic 
backwardness and poverty in the country have often been caused by remoteness and isolation, local roads and different modes of motorized transport are crucial for economic development and poverty alleviation. Similarly, communication goods like PO and PTO could reduce the disadvantages related to location and distance. Using principal components methods, we also generate a composite index PC_Comm of these four infrastructural goods. Further, we include access to two more essential infrastructural services, namely, banks and markets that could facilitate formal exchange, thus assisting the process of economic development. As such, inclusion of banks and markets would also allow us to test if the traditional communities have any aversion to formal modes of exchange (Kranton 1996). This allows us to include a second composite index PC_Exch. Finally, we compare the cases of these physical infrastructural goods with two important social infrastructural goods, namely, community's access to government health and schooling facilities.

Table 1 compares sample communities' access to various local public infrastructural goods between 1997 and 2007. In general there has been a significant improvement in the access to pucca road and public telegraph office over this period while there has been marginal increase in the access to electricity and market; in contrast, there has been reduction in the access to piped water, public transport, post office and bank. We also consider the corresponding allocation of development spending on social and physical infrastructure in the sample communities, also available from IFLS. Evidently, share of development spending has declined over the decade and this decline has been accompanied by a significant increase in share of development spending on physical infrastructural goods. Having considered this general trend over the decade, we next explore whether/how traditional communities differ from modern communities with respect to the provision of (or spending on) these goods and services in our sample.

\subsection{Social and religious norms}

Our analysis classifies communities according to their adherence to (a) adat laws and (b) Islam. Depending on the degree of adherence to adat laws, IFLS data classifies a community into 4 categories: (i) traditional laws are almost never broken; (ii) sometimes traditional laws are broken; (iii) traditional laws are frequently broken and (iv) only a few 
people understand traditional laws. ${ }^{5}$ We use this information to classify a community as 'adat' community (a binary variable labelled ADAT1) if adat laws are almost never broken; the variable takes a value zero otherwise. Second, IFLS data also provides information on the main religion practised in a community; thus a community is classified to be an Islamic community (a second binary variable labelled ISLAM) if Islam is the main religion. It is also important for us to identify the 'traditional Islamic communities' from the rest. About $28 \%$ of all communities strongly adhere to adat while as high as $86 \%$ of these adat communities had Islam as the main religion. Accordingly, we classify Islamic adat communities as 'traditional Islamic' communities to distinguish them from others labelled as 'modern Islamic' communities. In the absence of any direct information in this respect, we create an interaction term ADAT1*ISLAM to account for Islamic Adat communities. Alternatively, we construct a composite index of ISLAM and ADAT using principal component method, which is labelled as PCNORM.

Given the richness of the IFLS data, it is also possible to classify these communities according to their ethics of mutual co-operation, which we take to be a measure of collectivist culture. In particular, there is detailed community-level information on ethics of mutual cooperation as well as presence, if any, of mutual cooperation groups in these communities for various purposes including health, education, food security, security. As high as $94 \%$ of strictly adat (which are also predominantly Islamic) communities tend to have mutual cooperation groups; the proportion is about $70 \%$ for non-adat communities. The latter justifies, at least to some extent, our association of traditional adat communities to collectivist culture.

Demographic dimensions of traditional adat communities in our sample are worth noting. Table 2 shows that these communities tend to be strongly ethnically linked and predominantly rural in nature; often these communities are inhabited by a single large ethnic population group while the average population size is significantly smaller than non-traditional communities. Also the proportion of university educated population tends to be much less though the difference is significant only at about $10 \%$ level. Role of education could be important in influencing culture, as education can reduce the role of inherited cultural aspects in the formation of priors (e.g., see Guiso, Sapienza and Zingales, 2004). Also, compared to non-traditional communities, traditional communities

\footnotetext{
${ }^{5}$ This information is collected from the community leader or his/her assistants.
} 
have significantly lower access to selected physical infrastructural goods including public transport, post office, telegraph office, bank and market. These traditional communities are also more likely to be under-developed as measured by the proportion of communities receiving IDT funds. ${ }^{6}$ In contrast, share of government schools is significantly higher in traditional communities while that of government health facilities is not statistically different between traditional and modern communities.

There is also significant variation in average community characteristics across the provinces. Table 3 shows the summary statistics for the selected community characteristics across the sample provinces. In general, provinces with higher average population per community, higher proportion of university educated population and lower proportion of strongly adat communities tend to have better provision of all types of public infrastructural goods under consideration; these better off provinces also tend to have relatively lower proportion of under-developed communities. For example, the average community size is much bigger in Jakarta while influence of adat laws is rather negligible in the province; Jakarta is also the province with the lowest proportion of underdeveloped communities in the country, as against those in Bali or Wntenara, for example.

\section{EMPIRICAL ANALYSIS}

Provision of public infrastructure in a community highlights aspects of community organisation and preferences, which in turn depend on a number of community characteristics.

\subsection{Model specification}

Our objective in this section is to determine a community's access to different public infrastructural goods in our sample. First of all, we distinguish between social and physical infrastructural goods. We consider two social infrastructural goods, namely, a

\footnotetext{
${ }^{6}$ IDT or Inpres Deas Tertingadl was the primary antipoverty programme in the country and was targeted to the poorest communities. We use this information to classify sample communities as 'underdeveloped' if the community was selected for the implementation of IDT programmes; the rest of the communities are labelled 'developed'.
} 
community's access to government schools (Shgov_SCH), government health services (Shgov_HLTH); we also consider an index of communication infrastructural goods PC_Comm (involving PO, PTO, Proad and Pubtrans), an index of exchange infrastructural goods PC_Exch and a composite index of both communications and exchange infrastructural indexed by PC_GOOD1. We also have access to information on community level spending, which allows us to consider the corresponding allocation of total development spending; in particular, we consider a community's share of development spending on social infrastructural goods (SHSOC) and also that on physical infrastructural goods (SHINFRA). Finally, we consider the share of total spending allocated to development (SHDEV) as an index of overall development of the community.

In general, i-th community's access to a given public good $\mathrm{Y}_{\text {it }}$ in t-th year is determined as follows:

$$
\begin{gathered}
Y_{i t}=\beta_{0}+\beta_{1} \text { Adat }_{i t}+\beta_{2} \operatorname{Islam}_{i t}+\beta_{3} \text { Adat }_{i t} * \operatorname{Islam}_{i t}+\delta X_{i t} \\
+\alpha_{i}+\gamma_{t}+u_{i t}
\end{gathered}
$$

where $\mathrm{Y}$ refers to the particular public good or share of public spending under consideration. While a community's strong adherence to adat laws (Adat1) is used as an index of its social norms, its adherence to Islam (Islam) is the index for religious norms practised. We also include an interaction term between the two, i.e., Adat1*Islam to indicate if it is a traditional Islamic society. Alternatively, we also generate a composite socio-religious norm variable (PCNorm) using these two variables indicating community's strong adherence to adat and Islamic norms, which modifies equation (1) as follows:

$$
Y_{i t}=\theta_{0}+\theta_{1} \text { PCNorm }_{i t}+\theta_{X} X_{i t}+\eta_{i}+v_{t}+e_{i t}
$$

Note that $\alpha_{i}$ and $\eta_{i}$ are the unobserved time-invariant community-level fixedeffects (that does not change over time) in equations (1) and (2), controlling for community-level factors like government funding, external influences or administrator's preferences, affecting the provision of the particular public infrastructure in question. We also include $\gamma_{t}$ and $v_{t}$ respectively in (1) and (2), which are the unobserved year-specific 
fixed effects respectively in equations (1) and (2). Finally, $\mathrm{u}_{\mathrm{it}}$ and $e_{i t}$ are the idiosyncratic errors in (1) and (2), assumed to be distributed with zero mean and unit variance, which varies across community (i) and also over years (t).

There could be an important time trend whereby more traditional communities may change to a non-traditional one over time. In order to capture the interaction effect of culture and time trend, we also estimate the following equation (3):

$$
Y_{i}=\varphi_{0}+\varphi_{1} \text { PCNorm }_{i}+\varphi_{2} \text { Year }_{i}+\varphi_{3}(\text { Norm } * \text { Year })_{i}+\varphi_{X} X_{i t}+U_{i}
$$

Given our access to two-years (1997 \& 2007) panel data, we use panel data fixed effects OLS (FE-OLS) regression models to estimate equations (1) and (2) for various components of public goods and/or public spending in our sample. Since there are only two years, these FE-OLS estimates are also identical to the corresponding first difference estimates.

\subsection{Other control variables}

$\mathrm{X}_{\mathrm{it}}$ is the set of other control variables used to determine $\mathrm{Y}_{\mathrm{it}}$. Following the literature on public goods provision, we include measures pertaining to (i) group size and its sustainability, (ii) characteristics of the community leader; and also (iii) communityspecific other demographic and locational factors.

\section{Group size and its sustainability}

We consider population size of the community as an index of group size involved in the collective action. We also include square of population to explore if there is any nonlinear effect in this respect. It is also important to consider the factors that could enhance the long-term sustainability of public action in a community. To this end, we include the proportion of community households with at least junior secondary schooling since a higher proportion of more educated (as opposed to illiterate) households could be better placed to lobby for the sustainability of group efforts geared towards essential community causes. We also include square of the share of community households with junior high school education to explore if there is any non-linear effect in this respect. In an alternative specification, we also include community's mean monthly per capita household expenditure MPCE (both food and non-food items taken together) and also its 
square to test if the prosperity of the community too influences sustainability of collective action in our set-up.

\section{Characteristics of the community leader}

Since community government is the decision making unit in a decentralised set-up, characteristics of the community leader could be important in determining allocation of public spending or for that matter access to public goods. Community leaders are typically elected by popular votes and upon election they become members of the Indonesian Civil Service.

IFLS data allows us to identify the characteristics of the community leader. Given that the gender of the leader is endogenous to the choice of programme (note that As high as $97 \%$ community leaders is male in our sample), our analysis focuses on other relevant characteristics of the leader. In particular, we consider education (i.e., if the leader has college education or more COLLEGE) and also the years in position of the community leader (if the tenure is 10 years or more). ${ }^{7}$ While only about $28 \%$ leaders have college or higher education; about 38\% of community leaders have been in tenure for 10 years or more. We shall examine the possible role of these characteristics on the allocation of public spending and also access to social and physical infrastructure in sample communities.

\section{Other community characteristics}

Existing literature suggests that ethnic heterogeneity of a community could play an important role in the community's choice of public goods. 1997 and 2007 IFLS data provide the population information for three important ethnic groups in each community. We use this information to construct an index of ethnic heterogeneity using the formula $1-\sum \mathrm{p}_{\mathrm{i}}^{2}$ where $\mathrm{p}_{\mathrm{i}}$ is the population proportion of $\mathrm{i}$-th ethnic group in the community, $\mathrm{i}=1,2,3$. In addition, we include binary variables indicating whether a community is rural and also whether it has access to the sea since geographic location may also be important determinants of choice/access to public goods (e.g., see Barro 1999).

Table 4 shows the means and standard deviations of all the regression variables

\footnotetext{
${ }^{7}$ We also considered age of the head, but did not include it as it is closely correlated to the tenure in office.
} 
used in our analysis.

\section{RESULTS AND DISCUSSION}

We estimate a community's access to government schools, government health facilities, public communication goods as well as that to composite physical infrastructural goods. We also compare these estimates with the corresponding estimates for shares of development spending on social and physical infrastructural goods as well as share of total community spending on development. For each dependent variable of our choice, we start with the pooled ols estimates (see Table A1) and compare these with FE OLS estimates (Table 4). Appendix Table A2 shows the estimates derived from the conventional specification that excludes indices of social and religious norms. Estimates shown in Table 4 augments this baseline specification (Table A2) by three cultural variables, namely Adat1, Islam and Adat1*Islam. In particular, Columns 1-4 of Table 4 shows the FE OLS estimates of various public goods, namely, share of government schools, government health facilities, access to composite communications as well as physical infrastructural goods. Further, columns (5)-(7) of Table 4 show the corresponding FE OLS estimates of three public spending shares, namely, share of development spending on social infrastructure, physical infrastructure and also share of development spending in total spending. Table 5 shows the corresponding estimates when we replace the culture variables Adat1, Islam and Adat1*Islam by the composite culture variable PCNORM obtained by using the principal component analysis. Again columns (1)-(4) of Table 5 shows estimates for various public goods while those in columns (5)-(7) show those for various public spending accounts. Further, we consider separate estimates for public goods that promote formal exchange, namely, banks and market (see Appendix Table A3). Finally Appendix Table A4 shows the estimates of a community's access to public goods and public spending including an additional argument, namely mpce (and also its square term to explore aspects of non-linearity, if any).

Since culture is inherited at birth, we rule out estimation bias arising from reverse causality; nevertheless estimates could be biased because of unobserved heterogeneity. 
Since fixed effects estimates have the inherent property of minimising estimation bias arising from time-invariant unobserved heterogeneity, we prefer these estimates to ols estimates; we include both community and year specific unobserved heterogeneity. Finally, all standard errors are clustered at the community level; otherwise our estimates would have been biased. Estimates are generally robust and do not change with the change of specifications. Our discussion in the rest of the paper is primarily couched in terms of the complete estimates shown in Tables 4 and 5.

Our central hypothesis pertains to the role of cultural variables on a community's access to various public goods (columns 1-4, Tables 4 and 5) and also its shares of public spending on relevant accounts (columns 5-7, Tables 4 and 5). There is confirmation from Table 4, ceteris paribus, a community's strong adherence to Adat laws and Islamic religion (as reflected in the interaction term Adat $1 *$ Islam) tends to be associated with significantly lower access to composite communications goods, infrastructural goods as well as lower share of spending on infrastructure. In contrast, this interaction term is not statistically significant for the share of government schools and health facilities in our sample; more importantly, the coefficient of the interaction term turns out to be statistically significant and positive for share of spending on social infrastructure. These results are robust and hold when we replace Adat1, Islam and Adat1*Islam by the composite culture variable PCNORM as shown in Table 5, for example. In this case too, traditional communities, as measured by higher values of PCNORM, tend to have lower access to communication goods and also composite physical infrastructural goods; as before, share of spending on social goods is significantly higher while that on physical infrastructure is lower in more traditional communities. There is also evidence that traditional communities tend to have higher share of government schools. Estimates shown in Table A3 also indicate that Islamic communities tend to have significantly lower provision of exchange goods like banks and markets; the interaction term adat1*Islam is still negative, but not statistically significant. However the composite culture term PCNORM has a negative and statistically significant coefficient estimates. In other words, there is suggestion that these traditional communities may rely more on reciprocal exchange rather market-based exchange. 
Table A4 shows the estimates of a further augmented model when in addition to the earlier explanatory variables we include community-level mean per capita household expenditure and also its square term. In general results pertaining to our central hypothesis remain unchanged, which in turn highlight the beneficial role of traditional culture on promoting investment in social rather than physical infrastructural goods.

Among other factors, there is some confirmation that the average education level of the community plays an important role though the effect appears to be non-linear and also depends on the nature of the public goods in question. In particular, the first order effect is negative for social infrastructural goods while it is positive for physical infrastructural goods or for that matter share of spending on the provision of physical infrastructural goods. There is also evidence that the square term is significant and is of opposite sign to the linear term. Ethnic heterogeneity is significant and negative for the share of government health facilities and composite infrastructural goods; but remains insignificant for access to government schools in the community.

Regarding the effect of leader's characteristics, it appears that leader's characteristics are important only in the allocation of spending, but not so much in the community's access to public goods. In particular, communities with more educated leaders and also those with greater tenure in the job tend to have higher share of spending being allocated to physical infrastructural goods.

Geographic location of the community is also important. Thus, for example, rural communities tend to have lower share of development spending on physical infrastructural goods (shinfra) and also lower access to composite infrastructural goods (PCGood); similarly, a community with a border with the sea tends to have lower access to physical infrastructural goods.

To summarise, these results highlight the contrasting role of traditional collectivist culture on access to social (as opposed to physical) infrastructural goods and support our central hypothesis: holding other factors unchanged, traditional Islamic adat communities in Indonesia tend to have significantly more access to social rather than communications infrastructure. We argue that investment in traditional social infrastructure directly benefits its people and community, rather than promoting interaction with the outside world, which may dilute their indigenous way of life. Other things remaining unchanged, 
this traditionalism tends to impede investment in innovation, transport and communication, which can pave the way towards modern development.

\section{CONCLUSION}

The present paper goes beyond the existing literature to argue that local culture, i.e., religious and social norms, could explain a part of the variation in the choice and provision of public goods and also allocation of public spending in local communities in a decentralised set up. In this respect we distinguish between individualist and collective culture arguing that collective culture may promote family, social and religious values at the cost of individual values and may result in inefficient choice of pubic goods that may impede development.

Analysis using two rounds of Indonesian family life survey data and controlling for all possible covariates provide some support to our central hypothesis. There is evidence that traditional Islamic communities tend to have lower a provision of physical infrastructural goods like pucca road, motorized transport, post office, public telephone office, while preference is given to investment in social infrastructural goods like health and education facilities. While social infrastructural goods can contribute to exchange within/outside the community, investment in physical infrastructural goods could improve exchange outside the community and thereby innovation and growth of the region. A lower provision of physical infrastructural goods in traditional communities could thus highlight their attempt to preserve their indigenous way of life promoting collective culture. The latter however ignores the need for investment in physical infrastructure including roads, transport and communication, as poverty and backwardness is often a result of remoteness and isolation. 


\section{References}

Alberto Alesina \& Reza Baqir \& William Easterly, 1999. "Public Goods And Ethnic Divisions," The Quarterly Journal of Economics, MIT Press, vol. 114(4), pages 1243-1284.

Alesina, A. and E. La Farrara. 2005. Ethnic Diversity and Economic Performance', Journal of Economic Literature 63 pp. 762-800.

Bandeira, O. and G. Levy. 2007. 'The Diminishing Effect of Democracy in Diverse Societies', mimeo, London School of Economics, September.

Bardhan, P. and D. Mukherjee. 2002. 'Decentralisation of Governance and Development', Journal of Economic Perspectives, 185-205.

Beard, V. 2007. 'Household Contribution to Community Development in Indonesia', World Development 35(4), 607-25.

Besley, T., R. Pande. and V. Rao. 2005. Participatory Democracy in Action: Survey Evidence from India, Journal of European Economic Association Papers and Proceedings, Vol. 3 (2-3), pp. 648-657, April - May 2005.

Burroughs, J. and A. Rindfleisch. 2002. 'Materialism and Well-Being: A Conflicting Values Perspective’ The Journal of Consumer Research, Vol. 29 (3), pp. 348-370

Bowles and Gintis. 2004. 'Persistent Parochialism: Trust and Exclusion in Ethnic Networks’, Journal of Economic Behaviour and Organisation 55 pp. 1-23.

Chattopadhyay, R., and E. Duflo. 2004. 'Women as Policy Makers: Evidence from a India-Wide Randomized Policy Experiment', Econometrica, Vol. 72, pp. 1409-1443.

Easterlin, R. 1995. "Will Raising the Incomes of All Increase the Happiness of All?" Journal of Economic Behavior and Organization, 27:1 (June), 1995, 35-48.

Easterly, W. 2001. 'The Elusive Quest for Growth: Economists' Adventure and Misadventure in the Tropics', MIT Press, Cambridge.

Frankenberg, E. and D. Thomas. (2000). "'Study Design and Results from Waves 1 and 2," Santa Monica, CA, Rand, DRU - 2238, Volumes 1-7, NIA/NICH.

Grief, A. 1994. Cultural Beliefs and the Organization of Society: A Historical and Theoretical Reflection on Collectivist and Individualist Societies', Journal of Political Economy 102(5), pp. 912-50.

Guiso, Sapienza and Zingales. 2006. 'Does Culture Affect Economic Outcomes?' Journal of Economic Perspectives. 
Heine, S.J. 2007. ‘Cultural Psychology’, W.W. Norton \& Compnay.

Khawaja, A. 2008. 'Can Good Projects Succeed in Bad Communities ?' Journal of Public Economics (forthcoming).

Kranton. 1996. 'Reciprocal Exchange: A Self-Sustaining System', American Economic Review 86(4) pp. 830-51.

Kuran, T. 1997. 'Islam and Underdevelopment: An Old Puzzle Revisited', Journal of Institutional and Theoretical Economics.

Mansuri, G. and Rao. 2004. 'Community Based and Driven Development: A Critical Review’, World Bank Research Observer 19(1) 1-39.

Miguel, E. and M. Gugerty. 2005. 'Ethnic diversity, social sanctions, and public goods in Kenya', Journal of Public Economics, 89: 11, 2325

Narayanan and Pritchett. 1999. 'Cents and Sociability - Household Income and Social Capital in Rural Tanzania’, Economic Development and Cultural Change 47(4) 871-98.

Olken, B. 2007. Political Institutions and Local Public Goods, mimeo, Harvard University, February.

Pande, R. 2003. 'Can Mandated Political Representation Increase Policy Influence for Disadvantaged Minorities? Theory and Evidence from India', American Economic Review, Vol. 93, pp. 1132-1151.

Platteau, J-P. 2000. Institutions, Social Norms and Economic Development, Harwood Academic Publishers.

Putnam, R. 1993. Making Democracy Work, Princeton University Press, Princeton, NJ.

Reinikka, R. and J. Svensson. 2002. 'Coping with Poor Public Capital', Journal of Development Economics 69(1), pages 51-69.

Strauss, J., F. Witoelar, B. Sikoki and A. M. Wattie (2009). "The 4th Wave of the Indonesian Family Life Survey (IFLS4): Overview and Field Report," WR - 675/1 NIA/NICHD.

Wahhaj, Z. 2008. 'Social Norms and Individual Savings in the Context of Informal Insurance', CEDI discussion paper 08-20, Brunel University, UK.

Weber, M. 1905. The protestant Ethic and the Spirit of Capitalism, Routledge Classic, London, 2001. 
Tables

Table 1. Access to local infrastructure

\begin{tabular}{|c|c|c|c|c|}
\hline & 1997 & & 2007 & \\
\hline Variable & Mean & S.d. & Mean & s.d. \\
\hline Public transport & 0.7891 & 0.4086 & 0.75 & 0.4337 \\
\hline Public telephone office & 0.5112 & 0.5007 & 0.7532 & 0.4318 \\
\hline Post office & 0.2684 & 0.4438 & 0.2468 & 0.4318 \\
\hline Pucca Road & 0.8019 & 0.3992 & 0.9936 & 0.0799 \\
\hline Piped water & 0.6102 & 0.4884 & 0.5224 & 0.5002 \\
\hline Electricity & 0.9681 & 0.1761 & 0.9936 & 0.0799 \\
\hline Market & 0.3994 & 0.4906 & 0.4519 & 0.4985 \\
\hline Bank & 0.4026 & 0.4912 & 0.1859 & 0.3896 \\
\hline Share of govt schools & 0.3644 & 0.1872 & 0.6851 & 0.2072 \\
\hline Share of govt health facilities & 0.461 & 0.0525 & 0.6167 & 0.1745 \\
\hline $\begin{array}{l}\text { Share of dev. Spending on social } \\
\text { infrastructure }\end{array}$ & 0.1162 & 0.1156 & 0.1319 & 0.1970 \\
\hline $\begin{array}{l}\text { Share of dev. Spending on physical } \\
\text { infrastructure }\end{array}$ & 0.0709 & 0.0849 & 0.5128 & 0.3647 \\
\hline $\begin{array}{l}\text { Share of total spending on } \\
\text { development }\end{array}$ & 0.5473 & 0.4077 & 0.4812 & 0.2913 \\
\hline
\end{tabular}


Table 2. Inter-community heterogeneity, 1997-2007

\begin{tabular}{|c|c|c|c|}
\hline \multirow[b]{2}{*}{ Variables } & \multicolumn{3}{|c|}{ Community classification } \\
\hline & Traditional & $\begin{array}{c}\text { Non- } \\
\text { traditional }\end{array}$ & T-stat \\
\hline Access to bus & 0.24 & 0.38 & $-4.211 * *$ \\
\hline $\begin{array}{l}\text { Access to any motorized } \\
\text { public transport }\end{array}$ & 0.72 & 0.82 & $-2.767 * *$ \\
\hline Access to market & 0.32 & 0.46 & $-3.415 * *$ \\
\hline Access to PTO & 0.42 & 0.59 & $-3.399 * *$ \\
\hline Access to PO & 0.17 & 0.36 & $-4.820 * *$ \\
\hline Access to bank & 0.22 & 0.41 & $-4.478 * *$ \\
\hline Access to pucca Road & 0.66 & 0.82 & $-4.736 * *$ \\
\hline Access to electricity & 0.93 & 0.98 & $-2.496 * *$ \\
\hline Access to piped water & 0.46 & 0.65 & $-5.169 * *$ \\
\hline Share of government schools & 0.64 & 0.60 & $2.657 *$ \\
\hline $\begin{array}{l}\text { Share of government health } \\
\text { facilities }\end{array}$ & 0.57 & 0.58 & -1.285 \\
\hline Rural & 0.61 & 0.39 & $6.136 * *$ \\
\hline $\begin{array}{l}\text { District HQ or Provincial } \\
\text { capital }\end{array}$ & 0.18 & 0.21 & $-1.648^{*}$ \\
\hline Under-developed UNDEV & 0.18 & 0.14 & $1.780 *$ \\
\hline Strong adherence to adat & 1 & 0.05 & na \\
\hline If Islam is the main religion & 1 & 0.70 & na \\
\hline $\begin{array}{l}\text { Largest population group } \\
>90 \% \text { of total population }\end{array}$ & 0.91 & 0.78 & $10.411^{* *}$ \\
\hline $\begin{array}{l}\text { Proportion of households } \\
\text { with junior high school edn }\end{array}$ & 0.28 & 0.36 & $-7.273 * *$ \\
\hline $\begin{array}{l}\text { Proportion of university } \\
\text { educated households }\end{array}$ & 0.08 & 0.26 & $-5.014 * *$ \\
\hline Population (number) & 7040 & 11000 & $-5.357 * *$ \\
\hline
\end{tabular}


Table 3. Inter-province variation in selected community characteristics

\begin{tabular}{|c|c|c|c|c|c|c|}
\hline & \multicolumn{6}{|c|}{ Community characteristics } \\
\hline & \multirow[b]{2}{*}{ Population } & \multicolumn{4}{|c|}{ Mean (standard deviation) } & \multirow[b]{2}{*}{ Under-developed } \\
\hline & & $\begin{array}{l}\text { University educated } \\
\text { population }\end{array}$ & $\begin{array}{l}\text { Strong } \\
\text { adherence } \\
\text { adat laws }\end{array}$ & to & $\begin{array}{l}\text { Islam is the main } \\
\text { religion }\end{array}$ & \\
\hline Jakarta & $30023.25(14228.6)$ & $0.19(0.26)$ & $0.03(0.17)$ & & $0.31(0.46)$ & $0.11(0.32)$ \\
\hline West Java & $10056.3(9693.6)$ & $0.08(0.12$ & $0.20(0.40)$ & & $0.98(0.14)$ & $0.14(0.35)$ \\
\hline East Java & 7424.09 (5740.1) & $0.69(0.88)$ & $0.38(0.49)$ & & $0.96(0.21)$ & $0.24(0.43)$ \\
\hline Central Java & $6513.25(6275.7)$ & $0.12(0.32)$ & $0.20(0.40)$ & & $0.97(0.17)$ & $0.22(0.42)$ \\
\hline North Sumatra & $5562.9(5639.8)$ & $0.14(0.49)$ & $0.15(0.36)$ & & $0.46(0.50)$ & $0.19(0.40)$ \\
\hline South Sumatra & 3869.6 (2499.6) & $0.25(1.10)$ & $0.13(0.34)$ & & $0.87(0.34)$ & $0.20(0.40)$ \\
\hline West Sumatra & $2453.4(1099.2)$ & $0.11(0.15$ & $0.29(0.46)$ & & $0.93(0.26)$ & $0.21(0.42)$ \\
\hline Bali & 8624.3 (1599.6) & $0.19(0.22)$ & $0.50(0.51)$ & & $0(0)$ & $0.27(0.45)$ \\
\hline Wntenara & $8206.4(4621.3)$ & $0.05(0.71)$ & $0.50(0.63)$ & & $0.87(0.33)$ & $0.63(0.49)$ \\
\hline Ykarta & $13411.00(10081.7)$ & $0.19(0.25)$ & $0.26(0.44)$ & & $1.00(0.00)$ & $0.16(0.37)$ \\
\hline Lampung & $5016.09(2771.4)$ & $0.03(0.03)$ & $0.45(0.51)$ & & $0.81(0.39)$ & $0.27(0.45)$ \\
\hline Sulawesi & $4897.0(5218.15)$ & $0.08(0.13)$ & $0.63(0.49)$ & & $0.63(0.49)$ & $0.31(0.47)$ \\
\hline $\begin{array}{l}\text { South } \\
\text { Kalimantan }\end{array}$ & 3850 (4040.6) & $0.08(0.12)$ & $0.46(0.51)$ & & $0.85(0.37)$ & $0.15(0.37)$ \\
\hline
\end{tabular}

Note: Number in each indicates the proportion of total sample communities (except for population total). 
Table 4. FE OLS estimates of public goods and public spending

\begin{tabular}{|c|c|c|c|c|c|c|c|}
\hline VARIABLES & $\begin{array}{c}\text { (1) } \\
\text { shgov_sch }\end{array}$ & $\begin{array}{c}(2) \\
\text { shgov_hlth }\end{array}$ & $\begin{array}{c}\text { (3) } \\
\text { PCcomm }\end{array}$ & $\begin{array}{c}(4) \\
\text { pcgood1 }\end{array}$ & $\begin{array}{c}(5) \\
\text { Shsoc }\end{array}$ & $\begin{array}{c}(6) \\
\text { shinfra }\end{array}$ & $\begin{array}{c}(7) \\
\text { shdev }\end{array}$ \\
\hline Population & $\begin{array}{l}-1.08 \mathrm{e}-05 \\
(8.79 \mathrm{e}-06)\end{array}$ & $\begin{array}{c}2.23 \mathrm{e}-06 \\
(7.64 \mathrm{e}-06)\end{array}$ & $\begin{array}{c}2.27 e-05 \\
(4.77 e-05)\end{array}$ & $\begin{array}{c}5.11 \mathrm{e}-05 \\
(5.53 \mathrm{e}-05)\end{array}$ & $\begin{array}{l}-3.03 e-05 \\
(2.71 e-05)\end{array}$ & $\begin{array}{c}1.44 \mathrm{e}-05 \\
(2.76 \mathrm{e}-05)\end{array}$ & $\begin{array}{l}-3.93 \mathrm{e}-05 \\
(2.94 \mathrm{e}-05)\end{array}$ \\
\hline Sq(population) & $\begin{array}{c}5.48 \mathrm{e}-11 \\
(1.15 \mathrm{e}-10)\end{array}$ & $\begin{array}{c}0 \\
(1.03 \mathrm{e}-10)\end{array}$ & $\begin{array}{l}-2.22 \mathrm{e}-10 \\
(5.67 \mathrm{e}-10)\end{array}$ & $\begin{array}{l}-6.57 e-10 \\
(6.70 e-10)\end{array}$ & $\begin{array}{c}5.13 \mathrm{e}-10 \\
(3.18 \mathrm{e}-10)\end{array}$ & $\begin{array}{l}-2.66 e-10 \\
(3.49 e-10)\end{array}$ & $\begin{array}{c}6.23 \mathrm{e}-10 \\
(3.90 \mathrm{e}-10)\end{array}$ \\
\hline $\begin{array}{l}\text { Share of hh edn }>\text { JHS } \\
\text { (pjhs) }\end{array}$ & $\begin{array}{c}-0.922^{* * *} \\
(0.239)\end{array}$ & $\begin{array}{c}-1.092 * * * \\
(0.195)\end{array}$ & $\begin{array}{l}1.828 * \\
(0.963)\end{array}$ & $\begin{array}{c}0.860 \\
(0.882)\end{array}$ & $\begin{array}{l}-0.522 * \\
(0.294)\end{array}$ & $\begin{array}{c}1.942 * * * \\
(0.516)\end{array}$ & $\begin{array}{c}2.419 * * * \\
(0.638)\end{array}$ \\
\hline Sq(pjhs) & $\begin{array}{c}0.590 * * * \\
(0.190)\end{array}$ & $\begin{array}{c}0.633^{* * *} \\
(0.152)\end{array}$ & $\begin{array}{c}-2.041^{* * *} \\
(0.778)\end{array}$ & $\begin{array}{c}-1.812 * * * \\
(0.674)\end{array}$ & $\begin{array}{c}0.543^{* *} \\
(0.235)\end{array}$ & $\begin{array}{c}-1.209^{* * *} \\
(0.438)\end{array}$ & $\begin{array}{l}-0.904^{*} \\
(0.522)\end{array}$ \\
\hline Ethnic heterogeneity & $\begin{array}{l}0.0532 \\
(0.112)\end{array}$ & $\begin{array}{l}-0.105^{*} \\
(0.0606)\end{array}$ & $\begin{array}{c}-0.599 * * \\
(0.245)\end{array}$ & $\begin{array}{c}-0.567 * * \\
(0.257)\end{array}$ & $\begin{array}{c}0.0730 \\
(0.0945)\end{array}$ & $\begin{array}{l}-0.0403 \\
(0.184)\end{array}$ & $\begin{array}{l}-0.106 \\
(0.207)\end{array}$ \\
\hline Head edn $>=$ SHS & $\begin{array}{c}0.0335 \\
(0.0436)\end{array}$ & $\begin{array}{l}-0.00205 \\
(0.0312)\end{array}$ & $\begin{array}{l}-0.0198 \\
(0.174)\end{array}$ & $\begin{array}{l}0.0271 \\
(0.178)\end{array}$ & $\begin{array}{l}-0.0499 \\
(0.108)\end{array}$ & $\begin{array}{c}0.197 * * * \\
(0.0726)\end{array}$ & $\begin{array}{l}-0.165 \\
(0.111)\end{array}$ \\
\hline Tenure $>=10$ & $\begin{array}{c}0.0208 \\
(0.0333)\end{array}$ & $\begin{array}{l}-0.0247 \\
(0.0241)\end{array}$ & $\begin{array}{l}0.0336 \\
(0.128)\end{array}$ & $\begin{array}{l}-0.0249 \\
(0.124)\end{array}$ & $\begin{array}{l}-0.0718 \\
(0.0537)\end{array}$ & $\begin{array}{l}0.161^{* *} \\
(0.0708)\end{array}$ & $\begin{array}{c}-0.129 \\
(0.0968)\end{array}$ \\
\hline Rural & $\begin{array}{l}-0.0595 \\
(0.0709)\end{array}$ & $\begin{array}{l}-0.0365 \\
(0.0455)\end{array}$ & $\begin{array}{c}0.560 * * * \\
(0.193)\end{array}$ & $\begin{array}{c}-0.377 * * \\
(0.147)\end{array}$ & $\begin{array}{l}-0.0569 \\
(0.0449)\end{array}$ & $\begin{array}{l}-0.169 * * \\
(0.0818)\end{array}$ & $\begin{array}{c}0.199 \\
(0.145)\end{array}$ \\
\hline Sea & $\begin{array}{l}-0.0124 \\
(0.0179)\end{array}$ & $\begin{array}{l}-0.00869 \\
(0.0200)\end{array}$ & $\begin{array}{l}-0.194 * * \\
(0.0862)\end{array}$ & $\begin{array}{l}-0.169 * * \\
(0.0805)\end{array}$ & Dropped & Dropped & $\begin{array}{c}-0.0466 * * * \\
(0.0134)\end{array}$ \\
\hline Adat1 & $\begin{array}{c}0.0367 \\
(0.0565)\end{array}$ & $\begin{array}{c}0.0386 \\
(0.0670)\end{array}$ & $\begin{array}{c}0.587 * * * \\
(0.223)\end{array}$ & $\begin{array}{c}0.439 * * \\
(0.208)\end{array}$ & $\begin{array}{c}0.0879 \\
(0.0580)\end{array}$ & $\begin{array}{c}-0.326 * * * \\
(0.0798)\end{array}$ & $\begin{array}{l}-0.159 \\
(0.183)\end{array}$ \\
\hline Islam & $\begin{array}{c}0.154 * * * \\
(0.0385)\end{array}$ & $\begin{array}{c}0.0295 \\
(0.0313)\end{array}$ & $\begin{array}{c}-0.333^{* *} \\
(0.149)\end{array}$ & $\begin{array}{c}-0.515^{* * *} \\
(0.170)\end{array}$ & $\begin{array}{c}0.0714 \\
(0.0620)\end{array}$ & $\begin{array}{c}-0.263^{* * *} \\
(0.0942)\end{array}$ & $\begin{array}{c}0.0712 \\
(0.0997)\end{array}$ \\
\hline Adat1*Islam & $\begin{array}{l}-0.0429 \\
(0.0653)\end{array}$ & $\begin{array}{l}-0.0277 \\
(0.0727)\end{array}$ & $\begin{array}{c}-0.583^{* *} \\
(0.275)\end{array}$ & $\begin{array}{c}-0.517^{* *} \\
(0.262)\end{array}$ & $\begin{array}{c}0.187 * * * \\
(0.0612)\end{array}$ & $\begin{array}{c}-0.491^{* * *} \\
(0.110)\end{array}$ & $\begin{array}{l}0.365^{*} \\
(0.211)\end{array}$ \\
\hline Constant & $\begin{array}{c}0.582 * * * \\
(0.105)\end{array}$ & $\begin{array}{l}0.780 * * * \\
(0.0938)\end{array}$ & $\begin{array}{l}-0.250 \\
(0.477)\end{array}$ & $\begin{array}{c}0.206 \\
(0.540)\end{array}$ & $\begin{array}{c}0.452^{* * *} \\
(0.160)\end{array}$ & $\begin{array}{c}-0.523^{* *} \\
(0.244)\end{array}$ & $\begin{array}{c}0.103 \\
(0.303)\end{array}$ \\
\hline
\end{tabular}




\begin{tabular}{|c|c|c|c|c|c|c|c|}
\hline Community FE & Yes & Yes & Yes & Yes & Yes & Yes & Yes \\
\hline Year FE & Yes & Yes & Yes & Yes & Yes & Yes & Yes \\
\hline Observations & 419 & 416 & 422 & 422 & 269 & 271 & 411 \\
\hline R-squared & 0.808 & 0.704 & 0.315 & 0.266 & 0.258 & 0.694 & 0.233 \\
\hline Number of commid & 305 & 302 & 306 & 306 & 219 & 220 & 305 \\
\hline
\end{tabular}


Table 5.FE OLS estimates of public goods and public spending in terms of composite culture measure

\begin{tabular}{|c|c|c|c|c|c|c|c|}
\hline VARIABLES & $\begin{array}{c}\text { (1) } \\
\text { Sh_gov_sch }\end{array}$ & $\begin{array}{c}\text { (2) } \\
\text { Sh_gov_hlth }\end{array}$ & $\begin{array}{c}(3) \\
\text { PC_comm }\end{array}$ & $\begin{array}{c}(4) \\
\text { Pcgood }\end{array}$ & $\begin{array}{c}(5) \\
\text { Shsoc }\end{array}$ & $\begin{array}{c}\text { (6) } \\
\text { shinfra }\end{array}$ & $\begin{array}{c}(7) \\
\text { Shdev }\end{array}$ \\
\hline Population & $\begin{array}{c}-9.71 e-06 \\
(9.40 e-06)\end{array}$ & $\begin{array}{c}2.34 \mathrm{e}-06 \\
(7.59 \mathrm{e}-06)\end{array}$ & $\begin{array}{c}1.57 e-05 \\
(5.08 e-05)\end{array}$ & $\begin{array}{c}4.19 \mathrm{e}-05 \\
(6.01 \mathrm{e}-05)\end{array}$ & $\begin{array}{c}-2.84 \mathrm{e}-05 \\
(2.58 \mathrm{e}-05)\end{array}$ & $\begin{array}{c}-9.58 \mathrm{e}-07 \\
(3.00 \mathrm{e}-05)\end{array}$ & $\begin{array}{c}-3.55 e-05 \\
(2.99 e-05)\end{array}$ \\
\hline Square of Popn. & $\begin{array}{c}2.89 \mathrm{e}-11 \\
(1.23 \mathrm{e}-10)\end{array}$ & $\begin{array}{c}1.22 \mathrm{e}-11 \\
(1.04 \mathrm{e}-10)\end{array}$ & $\begin{array}{l}-1.54 \mathrm{e}-10 \\
(5.97 \mathrm{e}-10)\end{array}$ & $\begin{array}{l}-5.41 \mathrm{e}-10 \\
(7.09 \mathrm{e}-10)\end{array}$ & $\begin{array}{l}5.16 \mathrm{e}-10 * \\
(3.06 \mathrm{e}-10)\end{array}$ & $\begin{array}{l}-1.10 \mathrm{e}-10 \\
(3.69 \mathrm{e}-10)\end{array}$ & $\begin{array}{c}5.73 e-10 \\
(3.97 e-10)\end{array}$ \\
\hline Share of hhs $>=J H S$ (pjhs) & $\begin{array}{c}-1.046 * * * \\
(0.247)\end{array}$ & $\begin{array}{c}-1.133 * * * \\
(0.190)\end{array}$ & $\begin{array}{c}2.166^{* * *} \\
(0.971)\end{array}$ & $\begin{array}{c}1.454 \\
(0.915)\end{array}$ & $\begin{array}{c}-0.421 \\
(0.303)\end{array}$ & $\begin{array}{c}1.902 * * * \\
(0.560)\end{array}$ & $\begin{array}{c}2.167 * * * \\
(0.610)\end{array}$ \\
\hline Square of pjhs & $\begin{array}{c}0.667 * * * \\
(0.187)\end{array}$ & $\begin{array}{c}0.659 * * * \\
(0.148)\end{array}$ & $\begin{array}{c}-2.245 * * * \\
(0.753)\end{array}$ & $\begin{array}{c}-2.177 * * * \\
(0.680)\end{array}$ & $\begin{array}{c}0.492 * * \\
(0.244)\end{array}$ & $\begin{array}{c}-1.202 * * \\
(0.483)\end{array}$ & $\begin{array}{l}-0.720 \\
(0.508)\end{array}$ \\
\hline Ethnic heterogeneity & $\begin{array}{l}0.0459 \\
(0.121)\end{array}$ & $\begin{array}{l}-0.104^{*} \\
(0.0605)\end{array}$ & $\begin{array}{c}-0.518 * * \\
(0.260)\end{array}$ & $\begin{array}{c}-0.470 * \\
(0.282)\end{array}$ & $\begin{array}{c}0.0841 \\
(0.0929)\end{array}$ & $\begin{array}{c}-0.0643 \\
(0.188)\end{array}$ & $\begin{array}{l}-0.164 \\
(0.223)\end{array}$ \\
\hline Leaders edn. $>=$ shs & $\begin{array}{c}0.0574 \\
(0.0452)\end{array}$ & $\begin{array}{l}0.00822 \\
(0.0317)\end{array}$ & $\begin{array}{c}-0.0180 \\
(0.185)\end{array}$ & $\begin{array}{c}-0.0188 \\
(0.173)\end{array}$ & $\begin{array}{c}-0.0490 \\
(0.108)\end{array}$ & $\begin{array}{l}0.187 * * \\
(0.0772)\end{array}$ & $\begin{array}{l}-0.156 \\
(0.110)\end{array}$ \\
\hline Leader's tenure $>=10$ yrs & $\begin{array}{c}0.0329 \\
(0.0338)\end{array}$ & $\begin{array}{l}-0.0203 \\
(0.0249)\end{array}$ & $\begin{array}{l}0.0153 \\
(0.134)\end{array}$ & $\begin{array}{c}-0.0679 \\
(0.130)\end{array}$ & $\begin{array}{l}-0.0788 \\
(0.0559)\end{array}$ & $\begin{array}{l}0.166 * * \\
(0.0758)\end{array}$ & $\begin{array}{c}-0.103 \\
(0.0961)\end{array}$ \\
\hline Sea & $\begin{array}{l}-0.0165 \\
(0.0180)\end{array}$ & $\begin{array}{r}-0.00985 \\
(0.0191)\end{array}$ & $\begin{array}{l}-0.181 * * \\
(0.0827)\end{array}$ & $\begin{array}{l}-0.148 * \\
(0.0756)\end{array}$ & Dropped & dropped & $\begin{array}{c}-0.0542 * * * \\
(0.0149)\end{array}$ \\
\hline Pcnorm & $\begin{array}{c}0.0380 * * * \\
(0.0145)\end{array}$ & $\begin{array}{l}0.00142 \\
(0.0127)\end{array}$ & $\begin{array}{l}-0.133 * * \\
(0.0614)\end{array}$ & $\begin{array}{l}-0.146 * * \\
(0.0657)\end{array}$ & $\begin{array}{c}0.0347 \\
(0.0221)\end{array}$ & $\begin{array}{c}-0.0890 * * \\
(0.0396)\end{array}$ & $\begin{array}{l}-0.0173 \\
(0.0399)\end{array}$ \\
\hline Constant & $\begin{array}{c}0.723^{* * *} \\
(0.104)\end{array}$ & $\begin{array}{c}0.811^{* * * *} \\
(0.0818)\end{array}$ & $\begin{array}{l}-0.566 \\
(0.471)\end{array}$ & $\begin{array}{l}-0.308 \\
(0.561)\end{array}$ & $\begin{array}{c}0.454 * * * \\
(0.162)\end{array}$ & $\begin{array}{c}-0.598 * * \\
(0.249)\end{array}$ & $\begin{array}{c}0.244 \\
(0.283)\end{array}$ \\
\hline Community FE & Yes & Yes & Yes & Yes & Yes & Yes & Yes \\
\hline Year FE & Yes & Yes & Yes & Yes & Yes & Yes & Yes \\
\hline Observations & 419 & 416 & 422 & 422 & 269 & 271 & 411 \\
\hline R-squared & 0.793 & 0.701 & 0.278 & 0.194 & 0.231 & 0.644 & 0.192 \\
\hline Number of commid & 305 & 302 & 306 & 306 & 219 & 220 & 305 \\
\hline
\end{tabular}

Robust standard errors in parentheses; ${ }^{* * *} \mathrm{p}<0.01,{ }^{* *} \mathrm{p}<0.05,{ }^{*} \mathrm{p}<0.1$ 
Appendix

Table A1. Pooled OLS estimates of social and composite physical infrastructural goods

\begin{tabular}{|c|c|c|c|c|c|c|c|}
\hline VARIABLES & $\begin{array}{c}\text { (1) } \\
\text { shgov_sch }\end{array}$ & $\begin{array}{c}\text { (2) } \\
\text { shgov_hlth }\end{array}$ & $\begin{array}{c}(3) \\
\text { PCcomm } \\
\end{array}$ & $\begin{array}{c}(4) \\
\text { Pcgood1 }\end{array}$ & $\begin{array}{c}(5) \\
\text { shsoc }\end{array}$ & $\begin{array}{c}\text { (6) } \\
\text { shinfra }\end{array}$ & $\begin{array}{c}(7) \\
\text { Shdev }\end{array}$ \\
\hline Population & $\begin{array}{l}-4.84 \mathrm{e}-06 * \\
(2.68 \mathrm{e}-06)\end{array}$ & $\begin{array}{c}1.98 \mathrm{e}-06 \\
(1.56 \mathrm{e}-06)\end{array}$ & $\begin{array}{c}6.66 \mathrm{e}-05 * * * \\
(1.03 \mathrm{e}-05)\end{array}$ & $\begin{array}{c}8.81 \mathrm{e}-05^{* * *} \\
(1.09 \mathrm{e}-05)\end{array}$ & $\begin{array}{c}-1.22 \mathrm{e}-06 \\
(2.75 \mathrm{e}-06)\end{array}$ & $\begin{array}{l}-5.45 e-06 \\
(3.83 e-06)\end{array}$ & $\begin{array}{c}7.79 \mathrm{e}-06 \\
(5.51 \mathrm{e}-06)\end{array}$ \\
\hline Square of Popn. & $\begin{array}{c}2.90 \mathrm{e}-11 \\
(4.57 \mathrm{e}-11)\end{array}$ & $\begin{array}{l}-7.53 \mathrm{e}-12 \\
(3.04 \mathrm{e}-11)\end{array}$ & $\begin{array}{c}-8.28 \mathrm{e}-10 * * * \\
(1.81 \mathrm{e}-10)\end{array}$ & $\begin{array}{c}-1.02 \mathrm{e}-09 * * * \\
(1.88 \mathrm{e}-10)\end{array}$ & $\begin{array}{c}6.74 \mathrm{e}-11 \\
(4.66 \mathrm{e}-11)\end{array}$ & $\begin{array}{c}1.87 \mathrm{e}-11 \\
(7.42 \mathrm{e}-11)\end{array}$ & $\begin{array}{c}-9.09 \mathrm{e}-11 \\
(9.61 \mathrm{e}-11)\end{array}$ \\
\hline Share of hhs $>=$ JHS & $\begin{array}{c}-0.594^{* * *} \\
(0.155)\end{array}$ & $\begin{array}{c}-0.451 * * * \\
(0.0902)\end{array}$ & $\begin{array}{c}3.153^{* * * *} \\
(0.720)\end{array}$ & $\begin{array}{c}2.888 * * * \\
(0.698)\end{array}$ & $\begin{array}{l}0.0371 \\
(0.163)\end{array}$ & $\begin{array}{l}0.0133 \\
(0.266)\end{array}$ & $\begin{array}{l}0.747^{* *} \\
(0.346)\end{array}$ \\
\hline Square of pjhs & $\begin{array}{c}0.471 * * * \\
(0.155)\end{array}$ & $\begin{array}{l}0.405^{* * * *} \\
(0.0983)\end{array}$ & $\begin{array}{c}-2.117 * * * \\
(0.632)\end{array}$ & $\begin{array}{c}-2.119 * * * \\
(0.643)\end{array}$ & $\begin{array}{l}-0.0322 \\
(0.182)\end{array}$ & $\begin{array}{c}0.112 \\
(0.303)\end{array}$ & $\begin{array}{l}-0.485 \\
(0.338)\end{array}$ \\
\hline Ethnic heterogeneity & $\begin{array}{c}0.0355 \\
(0.0318)\end{array}$ & $\begin{array}{l}-0.0241 \\
(0.0162)\end{array}$ & $\begin{array}{l}-0.0925 \\
(0.165)\end{array}$ & $\begin{array}{l}-0.136 \\
(0.164)\end{array}$ & $\begin{array}{l}0.00598 \\
(0.0232)\end{array}$ & $\begin{array}{l}-0.0372 \\
(0.0398)\end{array}$ & $\begin{array}{c}-0.247 * * * \\
(0.0662)\end{array}$ \\
\hline Leaders edn. $>=$ shs & $\begin{array}{l}-0.00950 \\
(0.0245)\end{array}$ & $\begin{array}{c}0.0134 \\
(0.0118)\end{array}$ & $\begin{array}{l}0.254^{* *} \\
(0.120)\end{array}$ & $\begin{array}{c}0.128 \\
(0.118)\end{array}$ & $\begin{array}{l}0.00333 \\
(0.0249)\end{array}$ & $\begin{array}{c}0.0376 \\
(0.0267)\end{array}$ & $\begin{array}{l}-0.0388 \\
(0.0534)\end{array}$ \\
\hline Leader's tenure $>=10$ & $-0.0378 *$ & $-0.0157^{*}$ & 0.142 & $0.208 * *$ & 0.0152 & 0.00754 & -0.0528 \\
\hline yrs & $(0.0199)$ & (0.00909) & $(0.101)$ & $(0.102)$ & $(0.0201)$ & $(0.0227)$ & $(0.0441)$ \\
\hline Rural & $\begin{array}{l}0.00137 \\
(0.0273)\end{array}$ & $\begin{array}{l}-0.0216 \\
(0.0139)\end{array}$ & $\begin{array}{c}-0.309 * * \\
(0.134)\end{array}$ & $\begin{array}{c}-0.348 * * \\
(0.134)\end{array}$ & $\begin{array}{l}0.0531 * \\
(0.0275)\end{array}$ & $\begin{array}{l}-0.0464 \\
(0.0317)\end{array}$ & $\begin{array}{c}0.0255 \\
(0.0580)\end{array}$ \\
\hline Sea & $\begin{array}{c}-0.0228 * * \\
(0.00969)\end{array}$ & $\begin{array}{c}-0.000105 \\
(0.00401)\end{array}$ & $\begin{array}{l}-0.0790 \\
(0.0526)\end{array}$ & $\begin{array}{l}-0.102 * * \\
(0.0461)\end{array}$ & $\begin{array}{l}0.00519 \\
(0.0140)\end{array}$ & $\begin{array}{l}0.00547 \\
(0.0159)\end{array}$ & $\begin{array}{l}-0.0242 \\
(0.0194)\end{array}$ \\
\hline adat1 & $\begin{array}{l}0.0825 * \\
(0.0427)\end{array}$ & $\begin{array}{c}0.0411 \\
(0.0374)\end{array}$ & $\begin{array}{l}0.0253 \\
(0.195)\end{array}$ & $\begin{array}{c}0.131 \\
(0.180)\end{array}$ & $\begin{array}{c}0.0485 \\
(0.0442)\end{array}$ & $\begin{array}{c}-0.120 \\
(0.0725)\end{array}$ & $\begin{array}{l}-0.187 * \\
(0.0995)\end{array}$ \\
\hline Islam & $\begin{array}{c}0.0289 \\
(0.0266)\end{array}$ & $\begin{array}{l}0.0338 * \\
(0.0176)\end{array}$ & $\begin{array}{r}-0.0852 \\
(0.117)\end{array}$ & $\begin{array}{c}-0.156 \\
(0.132)\end{array}$ & $\begin{array}{c}0.0375 \\
(0.0257)\end{array}$ & $\begin{array}{l}-0.00129 \\
(0.0436)\end{array}$ & $\begin{array}{c}0.0129 \\
(0.0632)\end{array}$ \\
\hline Adat1*Islam & $\begin{array}{l}-0.0773 \\
(0.0480)\end{array}$ & $\begin{array}{l}-0.0479 \\
(0.0373)\end{array}$ & $\begin{array}{l}-0.196 \\
(0.215)\end{array}$ & $\begin{array}{l}-0.326^{*} \\
(0.195)\end{array}$ & $\begin{array}{l}-0.0524 \\
(0.0495)\end{array}$ & $\begin{array}{c}0.134 * \\
(0.0749)\end{array}$ & $\begin{array}{l}0.248 * * \\
(0.107)\end{array}$ \\
\hline Constant & $0.554 * * *$ & $0.534 * * *$ & $-1.428 * * *$ & $-0.902 *$ & 0.0591 & 0.128 & $0.660 * * *$ \\
\hline
\end{tabular}




\begin{tabular}{lccccccc} 
& $(0.0927)$ & $(0.0507)$ & $(0.456)$ & $(0.480)$ & $(0.0673)$ & $(0.0972)$ & $(0.158)$ \\
Districts & Yes & Yes & Yes & Yes & Yes & Yes & Yes \\
Year & Yes & Yes & Yes & Yes & Yes & Yes & 271 \\
Observations & 419 & 416 & 422 & 422 & 269 & 411 \\
R-squared & 0.556 & 0.583 & 0.591 & 0.556 & 0.162 & 0.511 & 0.179 \\
\hline \multicolumn{7}{r}{ Robust standard errors in parentheses; *** $\mathrm{p}<0.01, * * \mathrm{p}<0.05,{ }^{*} \mathrm{p}<0.1$}
\end{tabular}


Table A2. FE OLS Estimates of public goods without cultural variables

\begin{tabular}{|c|c|c|c|c|c|c|c|}
\hline VARIABLES & $\begin{array}{c}\text { (1) } \\
\text { shgov_sch }\end{array}$ & $\begin{array}{c}\text { (2) } \\
\text { shgov_hlth }\end{array}$ & $\begin{array}{c}\text { (3) } \\
\text { PCcomm }\end{array}$ & $\begin{array}{c}\text { (4) } \\
\text { pcgood1 }\end{array}$ & $\begin{array}{c}\text { (5) } \\
\text { shsoc }\end{array}$ & $\begin{array}{c}\text { (6) } \\
\text { shinfra }\end{array}$ & $\begin{array}{c}(7) \\
\text { Shdev }\end{array}$ \\
\hline \multirow[t]{2}{*}{ Population } & $-1.08 \mathrm{e}-05$ & $2.29 \mathrm{e}-06$ & $1.94 \mathrm{e}-05$ & $4.60 \mathrm{e}-05$ & $-3.13 e-05$ & $6.50 \mathrm{e}-06$ & $-3.56 e-05$ \\
\hline & (9.01e-06) & $(7.49 e-06)$ & (4.95e-05) & $(5.86 e-05)$ & (2.61e-05) & $(2.96 e-05)$ & $(3.02 \mathrm{e}-05)$ \\
\hline \multirow[t]{2}{*}{ Square of Popn. } & $4.03 e-11$ & $1.28 \mathrm{e}-11$ & $-1.94 \mathrm{e}-10$ & $-5.85 e-10$ & $5.61 \mathrm{e}-10^{*}$ & $-2.28 \mathrm{e}-10$ & $5.74 \mathrm{e}-10$ \\
\hline & $(1.20 \mathrm{e}-10)$ & (1.03e-10) & $(5.79 \mathrm{e}-10)$ & $(6.84 \mathrm{e}-10)$ & $(3.10 \mathrm{e}-10)$ & $(3.46 \mathrm{e}-10)$ & (3.99e-10) \\
\hline \multirow[t]{2}{*}{ Share of hhs $>=$ JHS } & $-1.038 * * *$ & $-1.133^{* * *}$ & $2.105 * *$ & 1.388 & -0.419 & $1.895 * * *$ & $2.167 * * *$ \\
\hline & $(0.249)$ & $(0.188)$ & $(0.966)$ & $(0.917)$ & $(0.315)$ & $(0.552)$ & $(0.614)$ \\
\hline \multirow[t]{2}{*}{ Square of pjhs } & $0.633 * * *$ & $0.657 * * *$ & $-2.101^{* * *}$ & $-2.017 * * *$ & $0.480 *$ & $-1.172 * *$ & -0.703 \\
\hline & $(0.190)$ & $(0.144)$ & $(0.771)$ & $(0.711)$ & $(0.251)$ & $(0.462)$ & $(0.504)$ \\
\hline \multirow[t]{2}{*}{ Ethnic heterogeneity } & 0.0172 & $-0.105^{*}$ & $-0.410 *$ & -0.350 & 0.0862 & -0.0694 & -0.151 \\
\hline & $(0.113)$ & $(0.0606)$ & $(0.244)$ & $(0.252)$ & $(0.0968)$ & $(0.186)$ & $(0.221)$ \\
\hline \multirow[t]{2}{*}{ Leaders edn. $>=$ shs } & 0.0493 & 0.00798 & 0.0118 & 0.0142 & -0.0335 & 0.148 & -0.153 \\
\hline & $(0.0457)$ & $(0.0316)$ & $(0.175)$ & $(0.165)$ & $(0.109)$ & $(0.0928)$ & $(0.109)$ \\
\hline \multirow[t]{2}{*}{ Leader's tenure $>=10$ yrs } & 0.0405 & -0.0201 & -0.0106 & -0.0965 & -0.0607 & 0.120 & -0.105 \\
\hline & $(0.0341)$ & $(0.0252)$ & $(0.134)$ & $(0.133)$ & $(0.0575)$ & $(0.0799)$ & $(0.0955)$ \\
\hline Rural & $(0.0650)$ & $(0.0412)$ & $(0.175)$ & $(0.135)$ & $(0.0388)$ & $(0.0836)$ & $(0.137)$ \\
\hline \multirow[t]{2}{*}{ Sea } & -0.0182 & -0.00991 & $-0.175 * *$ & $-0.142 *$ & dropped & dropped & $-0.0520 * * *$ \\
\hline & $(0.0184)$ & $(0.0189)$ & $(0.0819)$ & $(0.0765)$ & & & $(0.0135)$ \\
\hline \multirow[t]{2}{*}{ Constant } & $0.725 * * *$ & $0.811^{* * *}$ & -0.566 & -0.308 & $0.436 * *$ & $-0.551 * *$ & 0.245 \\
\hline & $(0.101)$ & $(0.0814)$ & $(0.467)$ & $(0.557)$ & $(0.170)$ & $(0.259)$ & $(0.285)$ \\
\hline Community FE & Yes & Yes & Yes & Yes & Yes & Yes & Yes \\
\hline Year FE & Yes & Yes & Yes & Yes & Yes & Yes & Yes \\
\hline Observations & 419 & 416 & 422 & 422 & 269 & 271 & 411 \\
\hline R-squared & 0.783 & 0.701 & 0.240 & 0.147 & 0.200 & 0.601 & 0.191 \\
\hline Number of commid & 305 & 302 & 306 & 306 & 219 & 220 & 305 \\
\hline
\end{tabular}

Robust standard errors in parentheses; *** $\mathrm{p}<0.01,{ }^{* *} \mathrm{p}<0.05$, * $\mathrm{p}<0.1$ 
Table A3. Estimates of market exchange goods

\begin{tabular}{|c|c|c|c|c|c|}
\hline VARIABLES & $\begin{array}{l}\text { (1) OLS } \\
\text { pcexch1 }\end{array}$ & $\begin{array}{c}\text { (2) FE } \\
\text { pcexch1 }\end{array}$ & $\begin{array}{c}\text { (3) FE } \\
\text { pcexch1 }\end{array}$ & $\begin{array}{l}\text { (4) FE } \\
\text { pcexch1 }\end{array}$ & $\begin{array}{c}\text { (5) FE } \\
\text { pcexch1 }\end{array}$ \\
\hline vpop & $\begin{array}{c}8.59 \mathrm{e}-05 * * * \\
(1.31 \mathrm{e}-05)\end{array}$ & $\begin{array}{c}8.09 \mathrm{e}-05 \\
(5.72 \mathrm{e}-05)\end{array}$ & $\begin{array}{c}8.65 \mathrm{e}-05 \\
(5.38 \mathrm{e}-05)\end{array}$ & $\begin{array}{c}7.74 \mathrm{e}-05 \\
(5.80 \mathrm{e}-05)\end{array}$ & $\begin{array}{c}9.04 \mathrm{e}-05 \\
(5.56 \mathrm{e}-05)\end{array}$ \\
\hline sqpop & $\begin{array}{c}-9.65 \mathrm{e}-10 * * * \\
(2.33 \mathrm{e}-10)\end{array}$ & $\begin{array}{l}-1.07 \mathrm{e}-09 \\
(6.92 \mathrm{e}-10)\end{array}$ & $\begin{array}{c}-1.18 \mathrm{e}-09^{*} \\
(6.82 \mathrm{e}-10)\end{array}$ & $\begin{array}{l}-1.03 e-09 \\
(7.10 \mathrm{e}-10)\end{array}$ & $\begin{array}{c}-1.23 \mathrm{e}-09^{*} \\
(7.10 \mathrm{e}-10)\end{array}$ \\
\hline pjhs & $\begin{array}{l}1.946 * * \\
(0.763)\end{array}$ & $\begin{array}{c}0.364 \\
(1.060)\end{array}$ & $\begin{array}{l}-0.336 \\
(1.012)\end{array}$ & $\begin{array}{c}0.421 \\
(1.060)\end{array}$ & $\begin{array}{l}-0.442 \\
(1.022)\end{array}$ \\
\hline sqpjhs & $\begin{array}{c}-1.708 * * \\
(0.712)\end{array}$ & $\begin{array}{l}-1.444^{*} \\
(0.841)\end{array}$ & $\begin{array}{l}-1.113 \\
(0.775)\end{array}$ & $\begin{array}{l}-1.581^{*} \\
(0.825)\end{array}$ & $\begin{array}{l}-1.031 \\
(0.794)\end{array}$ \\
\hline ethhety & $\begin{array}{l}-0.154 \\
(0.168)\end{array}$ & $\begin{array}{l}-0.261 \\
(0.347)\end{array}$ & $\begin{array}{l}-0.453 \\
(0.341)\end{array}$ & $\begin{array}{l}-0.363 \\
(0.367)\end{array}$ & $\begin{array}{l}-0.460 \\
(0.355)\end{array}$ \\
\hline headshs & $\begin{array}{l}-0.0362 \\
(0.132)\end{array}$ & $\begin{array}{l}0.0427 \\
(0.174)\end{array}$ & $\begin{array}{c}0.111 \\
(0.199)\end{array}$ & $\begin{array}{l}0.0145 \\
(0.172)\end{array}$ & $\begin{array}{c}0.115 \\
(0.196)\end{array}$ \\
\hline tenure10 & $\begin{array}{c}0.266^{* *} \\
(0.110)\end{array}$ & $\begin{array}{l}-0.135 \\
(0.140)\end{array}$ & $\begin{array}{c}-0.0469 \\
(0.136)\end{array}$ & $\begin{array}{l}-0.110 \\
(0.139)\end{array}$ & $\begin{array}{l}-0.0596 \\
(0.139)\end{array}$ \\
\hline rural & $\begin{array}{l}-0.301^{*} \\
(0.158)\end{array}$ & $\begin{array}{r}-0.0261 \\
(0.112)\end{array}$ & $\begin{array}{l}0.0991 \\
(0.147)\end{array}$ & $\begin{array}{c}0.141 \\
(0.138)\end{array}$ & $\begin{array}{l}0.0996 \\
(0.140)\end{array}$ \\
\hline sea & $\begin{array}{c}-0.128 * * * \\
(0.0487)\end{array}$ & $\begin{array}{l}-0.0676 \\
(0.109)\end{array}$ & $\begin{array}{l}-0.0979 \\
(0.105)\end{array}$ & $\begin{array}{l}-0.0730 \\
(0.105)\end{array}$ & $\begin{array}{l}-0.0960 \\
(0.106)\end{array}$ \\
\hline adat1 & $\begin{array}{c}0.274 \\
(0.231)\end{array}$ & & $\begin{array}{c}0.103 \\
(0.321)\end{array}$ & & $\begin{array}{c}0.149 \\
(0.329)\end{array}$ \\
\hline islam & $\begin{array}{l}-0.227 \\
(0.153)\end{array}$ & & $\begin{array}{c}-0.614^{* * *} \\
(0.189)\end{array}$ & & $\begin{array}{c}-0.613 * * * \\
(0.190)\end{array}$ \\
\hline adat1_islam & $\begin{array}{l}-0.415^{*} \\
(0.249)\end{array}$ & & $\begin{array}{l}-0.258 \\
(0.352)\end{array}$ & & $\begin{array}{l}-0.302 \\
(0.356)\end{array}$ \\
\hline pcnorm1 & & & & $-0.125 *$ & \\
\hline
\end{tabular}


mpce

$(0.0737)$

sqmpce

$-2.37 \mathrm{e}-08$
$(4.32 \mathrm{e}-08)$

Constant

$-0.0717$

(0.474)

$-0.164$

(0.601)

0.466

0

(0)

$(0.564) \quad(0.600)$

$\begin{array}{llllll}\text { Observations } & 422 & 422 & 422 & 422 & 422\end{array}$

$\begin{array}{lccccc}\text { R-squared } & 0.365 & 0.143 & 0.243 & 0.167 & 0.246\end{array}$

$\begin{array}{lllll}\text { Number of commid } & 306 & 306 & 306 & 306\end{array}$

Robust standard errors in parentheses; *** $\mathrm{p}<0.01,{ }^{* *} \mathrm{p}<0.05,{ }^{*} \mathrm{p}<0.1$ 
Table A4. FE OLS estimates of public goods and public spending with control for mpce

\begin{tabular}{|c|c|c|c|c|c|c|c|}
\hline VARIABLES & $\begin{array}{c}\text { (1) } \\
\text { shgov_sch }\end{array}$ & $\begin{array}{c}\text { (2) } \\
\text { shgov_hlth }\end{array}$ & $\begin{array}{c}\text { (3) } \\
\text { pcinfra1 }\end{array}$ & $\begin{array}{c}(4) \\
\text { pcgood1 }\end{array}$ & $\begin{array}{c}(5) \\
\text { shsoc }\end{array}$ & $\begin{array}{c}(6) \\
\text { shinfra }\end{array}$ & $\begin{array}{c}\text { (7) } \\
\text { shdev }\end{array}$ \\
\hline vpop & $\begin{array}{c}-1.12 \mathrm{e}-05 \\
(9.09 \mathrm{e}-06)\end{array}$ & $\begin{array}{c}-1.72 \mathrm{e}-06 \\
(8.08 \mathrm{e}-06)\end{array}$ & $\begin{array}{c}2.01 \mathrm{e}-05 \\
(4.99 \mathrm{e}-05)\end{array}$ & $\begin{array}{c}5.15 \mathrm{e}-05 \\
(5.88 \mathrm{e}-05)\end{array}$ & $\begin{array}{l}-3.51 \mathrm{e}-05 \\
(2.97 \mathrm{e}-05)\end{array}$ & $\begin{array}{c}1.46 \mathrm{e}-06 \\
(2.91 \mathrm{e}-05)\end{array}$ & $\begin{array}{c}-4.05 \mathrm{e}-05 \\
(3.02 \mathrm{e}-05)\end{array}$ \\
\hline sqpop & $\begin{array}{c}6.36 \mathrm{e}-11 \\
(1.14 \mathrm{e}-10)\end{array}$ & $\begin{array}{c}8.04 \mathrm{e}-11 \\
(1.15 \mathrm{e}-10)\end{array}$ & $\begin{array}{l}-1.64 \mathrm{e}-10 \\
(6.02 \mathrm{e}-10)\end{array}$ & $\begin{array}{l}-6.41 \mathrm{e}-10 \\
(7.18 \mathrm{e}-10)\end{array}$ & $\begin{array}{c}6.13 \mathrm{e}-10 \\
(4.42 \mathrm{e}-10)\end{array}$ & $\begin{array}{c}6.30 \mathrm{e}-11 \\
(5.05 \mathrm{e}-10)\end{array}$ & $\begin{array}{c}6.51 \mathrm{e}-10 \\
(3.96 \mathrm{e}-10)\end{array}$ \\
\hline pjhs & $\begin{array}{c}-0.910 * * * \\
(0.247)\end{array}$ & $\begin{array}{c}-1.012 * * * \\
(0.198)\end{array}$ & $\begin{array}{l}1.892^{*} \\
(0.962)\end{array}$ & $\begin{array}{c}0.840 \\
(0.875)\end{array}$ & $\begin{array}{l}-0.316 \\
(0.270)\end{array}$ & $\begin{array}{c}1.692^{* * *} \\
(0.499)\end{array}$ & $\begin{array}{c}2.443 * * * \\
(0.646)\end{array}$ \\
\hline sqpjhs & $\begin{array}{c}0.577 * * * \\
(0.196)\end{array}$ & $\begin{array}{c}0.562 * * * \\
(0.156)\end{array}$ & $\begin{array}{c}-2.113^{* * *} \\
(0.793)\end{array}$ & $\begin{array}{c}-1.819 * * * \\
(0.685)\end{array}$ & $\begin{array}{l}0.374^{*} \\
(0.223)\end{array}$ & $\begin{array}{c}-0.927 * * \\
(0.444)\end{array}$ & $\begin{array}{c}-0.934 * \\
(0.516)\end{array}$ \\
\hline mpce & $\begin{array}{c}6.62 \mathrm{e}-10 \\
(1.01 \mathrm{e}-08)\end{array}$ & $\begin{array}{l}1.47 \mathrm{e}-08^{* *} \\
(7.44 \mathrm{e}-09)\end{array}$ & $\begin{array}{c}6.63 \mathrm{e}-09 \\
(3.43 \mathrm{e}-08)\end{array}$ & $\begin{array}{l}-1.22 \mathrm{e}-08 \\
(3.74 \mathrm{e}-08)\end{array}$ & $\begin{array}{l}2.64 \mathrm{e}-08^{*} \\
(1.48 \mathrm{e}-08)\end{array}$ & $\begin{array}{c}-4.58 \mathrm{e}-08 * * \\
(1.94 \mathrm{e}-08)\end{array}$ & $\begin{array}{c}1.73 \mathrm{e}-09 \\
(2.97 \mathrm{e}-08)\end{array}$ \\
\hline ethhety & $\begin{array}{l}0.0479 \\
(0.114)\end{array}$ & $\begin{array}{l}-0.112^{*} \\
(0.0600)\end{array}$ & $\begin{array}{c}-0.624^{* *} \\
(0.257)\end{array}$ & $\begin{array}{c}-0.599 * * \\
(0.267)\end{array}$ & $\begin{array}{c}0.0388 \\
(0.0933)\end{array}$ & $\begin{array}{c}-0.00192 \\
(0.161)\end{array}$ & $\begin{array}{c}-0.122 \\
(0.207)\end{array}$ \\
\hline headshs & $\begin{array}{c}0.0314 \\
(0.0428)\end{array}$ & $\begin{array}{l}-0.0101 \\
(0.0303)\end{array}$ & $\begin{array}{c}-0.0336 \\
(0.176)\end{array}$ & $\begin{array}{c}0.0164 \\
(0.174)\end{array}$ & $\begin{array}{c}-0.0638 \\
(0.107)\end{array}$ & $\begin{array}{c}0.198 * * * \\
(0.0731)\end{array}$ & $\begin{array}{l}-0.171 \\
(0.107)\end{array}$ \\
\hline tenure10 & $\begin{array}{c}0.0213 \\
(0.0332)\end{array}$ & $\begin{array}{c}-0.0164 \\
(0.0229)\end{array}$ & $\begin{array}{l}0.0378 \\
(0.133)\end{array}$ & $\begin{array}{c}-0.0307 \\
(0.128)\end{array}$ & $\begin{array}{c}-0.0512 \\
(0.0640)\end{array}$ & $\begin{array}{l}0.110^{* *} \\
(0.0520)\end{array}$ & $\begin{array}{c}-0.127 \\
(0.0960)\end{array}$ \\
\hline rural & $\begin{array}{l}-0.0560 \\
(0.0701)\end{array}$ & $\begin{array}{c}-0.0286 \\
(0.0465)\end{array}$ & $\begin{array}{c}0.578 * * * \\
(0.198)\end{array}$ & $\begin{array}{c}0.395^{* * *} \\
(0.143)\end{array}$ & $\begin{array}{c}-0.0618 \\
(0.0395)\end{array}$ & $\begin{array}{c}-0.117 \\
(0.0918)\end{array}$ & $\begin{array}{c}0.208 \\
(0.139)\end{array}$ \\
\hline sea & $\begin{array}{l}-0.0124 \\
(0.0179)\end{array}$ & $\begin{array}{c}-0.00995 \\
(0.0198)\end{array}$ & $\begin{array}{c}-0.194^{* *} \\
(0.0871)\end{array}$ & $\begin{array}{l}-0.168 * * \\
(0.0825)\end{array}$ & Dropped & Dropped & $\begin{array}{c}-0.0463^{* * *} \\
(0.0143)\end{array}$ \\
\hline adat1 & $\begin{array}{c}0.0377 \\
(0.0611)\end{array}$ & $\begin{array}{c}0.0153 \\
(0.0612)\end{array}$ & $\begin{array}{c}0.588^{* *} \\
(0.232)\end{array}$ & $\begin{array}{c}0.476^{* *} \\
(0.223)\end{array}$ & $\begin{array}{c}0.0109 \\
(0.0615)\end{array}$ & $\begin{array}{l}-0.169 * \\
(0.0899)\end{array}$ & $\begin{array}{l}-0.158 \\
(0.190)\end{array}$ \\
\hline islam & $\begin{array}{c}0.153 * * * \\
(0.0386)\end{array}$ & $\begin{array}{c}0.0228 \\
(0.0331)\end{array}$ & $\begin{array}{c}-0.344^{* *} \\
(0.151)\end{array}$ & $\begin{array}{c}-0.525 * * * \\
(0.171)\end{array}$ & $\begin{array}{c}0.0589 \\
(0.0514)\end{array}$ & $\begin{array}{c}-0.255^{* * *} \\
(0.0763)\end{array}$ & $\begin{array}{c}0.0651 \\
(0.0986)\end{array}$ \\
\hline adat1_islam & $\begin{array}{l}-0.0438 \\
(0.0690)\end{array}$ & $\begin{array}{r}-0.00477 \\
(0.0683)\end{array}$ & $\begin{array}{c}-0.583 * * \\
(0.278)\end{array}$ & $\begin{array}{c}-0.552^{* *} \\
(0.268)\end{array}$ & $\begin{array}{c}0.106^{*} \\
(0.0610)\end{array}$ & $\begin{array}{c}-0.367 * * * \\
(0.120)\end{array}$ & $\begin{array}{l}0.365^{*} \\
(0.221)\end{array}$ \\
\hline Constant & $0.584 * * *$ & $0.797 * * *$ & -0.230 & 0.224 & $0.451^{* * *}$ & $-0.441^{* *}$ & 0.115 \\
\hline
\end{tabular}




\begin{tabular}{lccccccc} 
& $(0.105)$ & $(0.0969)$ & $(0.484)$ & $(0.552)$ & $(0.166)$ & $(0.218)$ & $(0.308)$ \\
Community FE & Yes & Yes & Yes & Yes & Yes & Yes & Yes \\
District FE & Yes & Yes & Yes & Yes & Yes & 269 & Yes \\
Observations & 419 & 416 & 422 & 422 & 269 & 411 \\
R-squared & 0.808 & 0.716 & 0.317 & 0.271 & 0.310 & 0.763 & 0.235 \\
Number of commid & 305 & 302 & 306 & 306 & 219 & 220 & 305 \\
\hline
\end{tabular}

Robust standard errors in parentheses

$$
* * * \mathrm{p}<0.01,{ }^{* *} \mathrm{p}<0.05,{ }^{*} \mathrm{p}<0.1
$$

